BIOMEDICAL AND BIOSOCIAL ANTHROPOLOGY
$\begin{gathered}\text { Official Journal of the International Academy } \\ \text { of Integrative Anthropology } \\ \text { journal homepage: http://bba-journal.com }\end{gathered}$

\title{
Features of emotional burnout of students in the conditions of pre- examination and examination academic stress
}

Serebrennikova O. A., Makarov S. Yu.

National Pirogov Memorial Medical University, Vinnytsya, Ukraine

\section{ARTICLE INFO}

Received: 26 December 2018

Accepted: 23 January 2019

UDC: $159.944 .4: 61: 378.4: 616-053.82$

\section{CORRESPONDING AUTHOR}

e-mail: doctor_makarov@ukr.net Makarov S. Yu.
An important place in the structure of personality traits of student youth, who possesses a certain specialty and is in the conditions of pre-examination and examination academic stress, belongs to the leading characteristics of the level of expression of emotional burnout, which is an indisputable factor of formation of high level of emotional instability of young women and young men to the effects of environmental factors and social and professional living conditions. The aim of the study is to study the peculiarities of emotional burnout of students of higher medical education institutions, who are in the conditions of pre-examination and examination academic stress. The studies were conducted at the National Pirogov Memorial Medical University among 67 students of the 3rd year of the Faculty of Medicine, respectively, 1 month before the preparation and immediately before the period of differentiated tests and the examination session with the use of a personal Boyko questionnaire. The statistical analysis of the data obtained, which involved the use of descriptive statistics procedures, was carried out on the basis of using the standard statistical analysis application package "Statistica 6.1" (license number AXX910A374605FA). The results show a significant increase in the level of expression of all the leading phases of emotional burnout of students during the pre-examination and examination periods, and most of all this phenomenon relates to the most unfavorable in its content of phases of resistance and exhaustion. It is established that the level of expression of the leading characteristics of emotional burnout in the highest proportion of young women and young men is characterized by being in the phase of resistance. The highest level of expression of emotional burnout phase indicators in both young women and young men is characteristic for the period of 1 month before the examination session, however, the highest level of expression of phase indicators depletion in both young women and young men is observed immediately before the examination session. Young women have a more significant degree of expression of values that mark the leading components of the resistance phase, among young men - values that mark the leading indicators of the phases of stress and exhaustion. The determined data are of significant importance both from the standpoint of determining the features of the formation of adaptation resources of the organism, and from the standpoint of establishing practically significant approaches to the formation of students' personality, which provide the necessary for successful mastering of the future profession of the working dynamic stereotype of the teaching and professional activity prevention of unwanted emotional reactions in response to the factors of educational or work process.

Keywords: students, institutions of higher medical education, emotional burnout, preexamination and examination academic stress.

\section{Introduction}

Admission to higher education institutions of various profiles, including institutions of higher medical education, and the further process of education and gaining medical profession, based on a number of objective reasons, as evidenced by the data of research conducted in recent years, related with the influence on the body of young women and young men of a multifaceted complex of stressful factors, which include, first of all, the following: intensive training load, a sharp change in the closest social microenvironment and the need to establish new social 
contacts, insufficient time for adequate sleep and low motor activity, significant financial burden on the family budget, the need for contact with suffering patients, etc. $[3,7,11$, 20, 24-28].

Another, no less important in its content, is the problem of overcoming pre-examination and exam training stress, which, undoubtedly, should be considered as a very powerful factor that causes the emergence of pronounced psycho-emotional stress of the body and the phenomena of psychological discomfort of student youth and disorders , processes of psychophysiological and mental adaptation, since it represents a kind of critical situation, the result of which can produce an immediate, as well as the negative impact on the position of individual young women and young men in a particular higher education institution, their social status, and, without exaggeration, changing their future destiny $[4,5,12]$.

In addition to the additional circumstances that significantly exacerbate the stressful impact of pre-exam and exam periods on the student body, it is necessary to emphasize the need to maximize their knowledge and skills over a very short period of time, as well as the element of chance associated with obtaining the exam task takes place. Such factors become a real test for future specialists in stress resistance, which, to date, is no less important indicator of professional suitability and professional competence than the level of qualification, the degree of communication skills and the ability to continuous selfimprovement [2, 5, 6, 9, 13].

Moreover, a special place in the structure of personality traits of student youth, who possesses a certain specialty and is in the conditions of pre-examination and exam training stress, belongs to the leading characteristics of the level of expression of emotional burnout, which is an indisputable factor of formation of a high level of emotional instability of the investigated persons to the influence of environmental factors and social and professional living conditions, as well as the tendency to develop various disorders of the characteristics of the mental sphere of their organism due to the influence of psycho-traumatic factors, which are actually considered similar situations $[5,8,18,21]$.

The purpose of the work is to investigate the peculiarities of emotional burnout of students of higher medical education institutions, who are in the conditions of preexam and exam training stress.

\section{Materials and methods}

The studies were conducted at the National Pirogov Memorial Medical University, Vinnytsya among the students of the 3rd year of the Faculty of Medicine, respectively, 1 month before the preparation and immediately before the period of differentiated tests and the examination session. In total, 67 students, including 35 young women and 32 young men, were observed in the dynamics of observations.

In order to determine the indicators of emotional burnout, a personal Boyko questionnaire, widely used in the practice of psychodiagnostic research, was used, which allowed to identify 12 symptoms that form 3 phases of emotional burnout, namely: the phase of alarm voltage, which includes the symptoms of experiencing psychotraumatic trauma, feeling "caged", anxiety and depression, a phase of resistance that includes in its structure symptoms of inadequate selective emotional burnout, emotional and moral disorientation, expansion of emotions saving and reduction of professional duties and exhaustion phase consisting of symptoms of emotional deficits, emotional and personal detachment and psychosomatic and psycho-vegetative disorders [22].

For each of the symptoms were distinguished 3 stages of development - a symptom that is unformed (up to 9 points), a symptom that is forming (10-15 points) and a symptom that has been already formed (more than 16 points). Accordingly, each phase of development of emotional burnout was defined as unformed (up to 37 points on the set of symptoms that make up it), forming (37-60 points on the set of symptoms that make up it), and already formed (more than 60 points on the set of symptoms that make up it).

Statistical analysis of the obtained data, which included the use of descriptive statistics procedures and comparison of the obtained results on the basis of statistical criteria of parametric statistics (Student's t-test), was carried out on the basis of using the standard package of multidimensional statistical analysis "Statistica 6.1" (license number AXX910A374605FA belongs to National Pirogov Memorial Medical University, Vinnytsya).

\section{Results}

During the researches and the analysis of indicators of the degree of expression of such phase of development of emotional burnout, as the phase of alarm voltage (the first, initial, phase of emotional burnout), which certifies the appearance and further spread of certain psychophysiological and psycho-significant manifestations of certain exhaustiveness of personality and personality feeling of being in a state of constant tension and psychological discomfort, it should be noted that the level of her indicators in young women 1 month before the exam session was $42.82 \pm 3.38$ points, in young men - amounted to $45.09 \pm 3.65$ points, at the same time, just before the exam session - in both cases, there was a tendency for their growth, which, however, was not marked by the presence of statistically significant differences, reaching respectively $51.54 \pm 4.04$ points $\left(20.3 \% ; \mathrm{p}(\mathrm{t})_{1-\mathrm{e}}>0.05\right)$ among the first and $46.93 \pm 4.30$ points $\left(4.0 \% ; \mathrm{p}(\mathrm{t})_{1-\mathrm{e}}>0.05\right)$ - among the second (Table 1). A higher level of expression of indicators of the phase of stress at the beginning and at the end of the observation period was typical for young men. No genderrelated differences were recorded $\left(p(t)_{w-m}>0.05\right)$.

While conducting an in-depth assessment of the degree of expression of the individual components of the alarm 
Table 1. Indicators of the level of emotional burnout of students in the pre-exam and exam periods of study in a higher medical institution according to the personal questionnaire by Boyko (points).

\begin{tabular}{|c|c|c|c|c|c|c|}
\hline \multirow{3}{*}{$\begin{array}{l}\text { Indicators of the main } \\
\text { phases of emotional burnout }\end{array}$} & \multirow{3}{*}{ Research period } & \multicolumn{4}{|c|}{ Groups of students } & \multirow{3}{*}{$p(t)_{w-m}$} \\
\hline & & \multicolumn{2}{|c|}{ Young women } & \multicolumn{2}{|c|}{ Young men } & \\
\hline & & $\mathrm{n}$ & $\mathrm{M} \pm \mathrm{m}$ & $\mathrm{n}$ & $\mathrm{M} \pm \mathrm{m}$ & \\
\hline \multirow{3}{*}{$\begin{array}{l}\text { The level of expression of } \\
\text { the indicators of the phase of } \\
\text { alarm voltage }\end{array}$} & 1 month before the exam session & 35 & $42.82 \pm 3.38$ & 32 & $45.09 \pm 3.65$ & $>0.05$ \\
\hline & Before the exam session & 35 & $51.54 \pm 4.04$ & 32 & $46.93 \pm 4.30$ & $>0.05$ \\
\hline & $p(t)_{1-e}$ & \multicolumn{2}{|l|}{$>0.05$} & \multicolumn{2}{|l|}{$>0.05$} & \\
\hline \multirow{3}{*}{$\begin{array}{l}\text { The level of expression of } \\
\text { resistance phase indicators }\end{array}$} & 1 month before the exam session & 35 & $50.25 \pm 5.38$ & 32 & $46.09 \pm 4.82$ & $>0.05$ \\
\hline & Before the exam session & 35 & $64.62 \pm 3.06$ & 32 & $57.15 \pm 3.42$ & $>0.05$ \\
\hline & $p(t)_{1-\mathrm{e}}$ & \multicolumn{2}{|l|}{$<0.05$} & \multicolumn{2}{|l|}{$>0.05$} & \\
\hline \multirow{3}{*}{$\begin{array}{l}\text { The level of expression of } \\
\text { the exhaustion phase } \\
\text { indicators }\end{array}$} & 1 month before the exam session & 35 & $40.45 \pm 3.58$ & 32 & $42.59 \pm 3.90$ & $>0.05$ \\
\hline & Before the exam session & 35 & $51.54 \pm 2.04$ & 32 & $54.12 \pm 3.90$ & $>0.05$ \\
\hline & $p(t)_{1-\mathrm{e}}$ & \multicolumn{2}{|l|}{$<0.05$} & \multicolumn{2}{|l|}{$<0.05$} & \\
\hline
\end{tabular}

voltage phase, it should be noted that both young women and young men 1 month before the exam session were the most significant, which reflected the experiences of psychotraumatic circumstances (respectively $24.97 \pm 3.38$ points and $24.90 \pm 2.93$ points) and dissatisfaction with oneself (respectively $15.20 \pm 2.93$ points and $18.81 \pm 3.27$ points), followed by the characteristics of anxiety and depression (respectively $13.68 \pm 1.59$ points and $13.59 \pm 1.50$ points) and the feeling of being "caged" (respectively $6.80 \pm 1.10$ points and $9.15 \pm 1.41$ points), at the same time, immediately before the examination session - data that reflected the characteristics of anxiety and depression (respectively $17.74 \pm 1.60$ points and $15.31 \pm 1.66$ points) and experiences of psycho-traumatic circumstances (respectively $14.48 \pm 1.38$ and $14.34 \pm 1.63$ points), followed by characteristics regarding dissatisfaction with themselves (respectively $9.97 \pm 1.07$ points and $11.31 \pm 1.27$ points) and the feeling of being "caged" ( $9.00 \pm 1.49$ points and $9.12 \pm 1.50$ points, respectively).

Considering the indicators of the level of development of such a component of emotional burnout, as the degree of expression of the phase of resistance (the second, intermediate, phase of emotional burnout), which testifies to the presence of signs of the development of naturalconditioned resistance of the organism to the influence of various types of emotional load inherent in life, characteristic of the modern student life, it should be noted that the level of expression of it indicators in young women 1 month before the exam session was $50.25 \pm 5.38$ points, in young men $46.09 \pm 4.82$ points, however, just before the examination session - its values increased statistically and significantly, reaching $64.62 \pm 3.06$ points $\left(28.5 \% ; \mathrm{p}(\mathrm{t})_{1-\mathrm{e}}<0.05\right)$ in the first case and showing a trend towards growth, which, however, did not statistically significant features, reaching respectively the level of $57.15 \pm 3.42$ points $\left(23.9 \%\right.$; $\left.p(t)_{1-e}>0.05\right)$ - in the second. In contrast to the previous case, a higher level of expression of resistance phase indicators at the beginning and at the end of the observation period was typical for young women. No gender-related differences were recorded $\left(p(t)_{w-m}>0.05\right)$.

When assessing the degree of expression of the individual components of the resistance phase, it should be noted that 1 month before the exam session, the most significant were the data that reflected inadequate selective emotional response (respectively $19.28 \pm 1.23$ points and $16.15 \pm 1.27$ points) and reduction of vocationally-oriented teaching responsibilities (respectively $15.71 \pm 1.50$ points and $15.53 \pm 1.44$ points), followed by the characteristics of expanding the sphere of saving emotions (respectively $15.14 \pm 1.61$ points and $13.62 \pm 1.40$ points) and emotional and moral disorientation (respectively $11.22 \pm 1.23 \mathrm{~b}$ and $13.78 \pm 1.43$ points), at the same time, immediately before the exam session - data that reflected inadequate selective emotional response (respectively $19.62 \pm 1.27$ points and $15.62 \pm 1.44$ points) and reduction of vocationally-oriented teaching responsibilities (respectively $18.80 \pm 1.09$ points and $16.25 \pm 1.44$ points), followed by the characteristics of expanding the sphere of emotions saving (respectively $17.48 \pm 1.45$ points and $13.06 \pm 1.25$ points) and, in particular, emotional and moral disorientation (respectively $8.71 \pm 1.14$ points and $12.68 \pm 1.20$ points).

After all, during the evaluation of the peculiarities of the spread of personal manifestations inherent in such a phase of emotional burnout development as the exhaustion phase (the third, the last, the emotional burnout phase), the remarkable characteristics of which are a significant reduction in the level of functional resources and quite real exhaustion of adaptation organisms found that the level of it indicators for young women 1 month before the exam session was $40.45 \pm 3.58$ points, for young men - $42.59 \pm 3.90$ points, at the same time, just before the exam session - in both cases, there were statistically significant differences, reaching respectively $51.54 \pm 2.04$ points $\left(27.4 \%\right.$; $\left.p(t)_{1-\mathrm{e}}<0.05\right)$ among the first and $54.12 \pm 3.90$ points $\left(27.0 \%\right.$; $\left.\mathrm{p}(\mathrm{t})_{1-\mathrm{e}}<0.05\right)$ - among second. A higher level of expression of the exhaustion phase indices at the beginning and at the end of the observation period was typical for young men. No gender- 


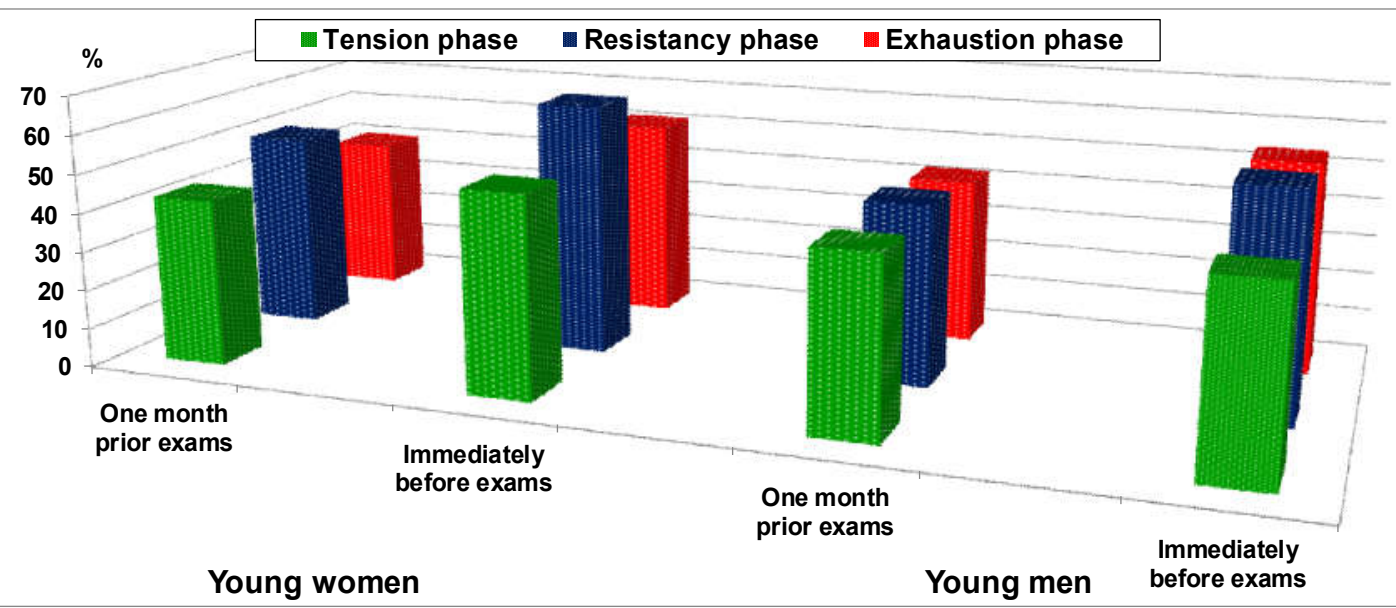

Fig. 1. Features of students' distribution according to the degree of expression of the leading phases of indicators of emotional burnout of students in pre-examination and examination periods of study at a higher medical education institution according to the personal Boyko questionnaire.

related differences were recorded $\left(p(t)_{w-m}>0.05\right)$.

Analyzing the degree of expression of the individual components of the exhaustion phase, it should be noted that among young women and young men 1 month before the exam session among young women, the most significant were the data reflecting the presence of emotional deficit $(13.20 \pm 1.28$ points) and the level of personal distance (11.68 \pm 1.68 points), followed by characteristics regarding the level of emotional distance (10.28 \pm 1.08 points) and the level of expression of psychosomatic and psycho-vegetative shifts (10.00 \pm 1.17 points), among young men - data that reflected the level of personal distance woundedness (14.37 \pm 1.14 points) and the presence of emotional deficiency (13.78 \pm 1.29 points), followed by characteristics regarding the level of personal distance $(12.75 \pm 1.66$ points) and the level of expression of psychosomatic and psychoautonomic shifts $(8.06 \pm 1.19$ points $)$. At the same time, immediately before the exam session, the observed pattern was the same for young women and young men - data that reflected the presence of emotional deficit (respectively $13.60 \pm 1.20$ points and $14.59 \pm 1.14$ points) and the level of personal distance (respectively $15.80 \pm 2.89$ points and $14.56 \pm 1.86$ points), followed by characteristics regarding the level of emotional detachment (respectively 13.54 \pm 1.12 points and $13.87 \pm 1.23$ points) and, in particular, the expression level of psychosomatic and psycho-autonomic shifts (respectively $13.48 \pm 1.26$ points and $9.84 \pm 1.12$ points).

Data on the characteristics of student distribution according to the degree of expression of the leading phases of the indicators of emotional burnout of students in the preexamination and examination periods based on the use of a personal Boyko questionnaire are shown in Figure 1.

The obtained results indicate an increase in the proportion of indicators of the expression of all leading phases of emotional burnout of the students to be studied during the pre-examination and examination periods (1 month before the beginning of the examination session and immediately before the beginning of the exam) and most of all this phenomenon concerns the most unfavorable in its content such phases as the phases of resistance and exhaustion. In young women recorded a more significant degree of expression, which noted the leading components of the resistance phase, among young men - the leading indicators of the phases of alarm voltage and exhaustion.

It should be noted that the level of expression of the leading characteristics of emotional burnout of the largest part of subjects was characterized by being in the resistance phase, respectively, $50.25 \pm 5.38$ points in young women and $46.09 \pm 4.82$ points in young men 1 month before the exam session, respectively $64.62 \pm 3.06$ points $\left(p(t)_{1-e}<0.05\right)$ in young women and $57.15 \pm 3.42$ points $\left(\mathrm{p}(\mathrm{t})_{1-\mathrm{e}}>0.05\right)$ in young men - immediately before the exam session. However, the highest level of expression of the indicators of the phase of alarm voltage among both young women and young men was characteristic for the period 1 month before the examination session $\left(51.54 \pm 2.04\right.$ points $\left(p(t)_{1-\mathrm{e}}>0.05\right)$ respectively in the first case and $54.12 \pm 3.90$ points $\left(p(t)_{1-e}>0.05\right)$ - in the second), instead, the highest level of expression of indicators of the exhaustion phase in both young women and young men was characteristic for the period immediately before the examination session $\left(51.54 \pm 2.04\right.$ points, respectively $\left.(p(t))_{1-e}<0.05\right)$ in the first case and $54.12 \pm 3.90$ points $\left(p(t)_{1-\mathrm{e}}<0.05\right)$ in the second).

\section{Discussion}

According to the current scientific literature, medical students in various countries of the world tend to have relatively high levels of anxiety, asthenia, and depression and necessarily exhibit the initial signs of emotional burnout [10-12, 14, 15, 19, 23, 28, 29].

The phenomena identified can serve as an important prerequisite for a decline in academic performance, a decrease in the level of motivation to develop the necessary professional skills and qualities, a decrease in the capacity 
for empathy, and therefore a sympathy, even leading to the development of so-called "professional cynicism" which has peculiar manifestations and is marked by a kind of "coloration" [7, 16, 27, 30].

In this regard, it is extremely important and urgent task to develop methods for assessing and predicting the features of the course of psychophysiological adaptation, which form a certain degree of anxiety, depressive and asthenic states, aggressive manifestations, as well as a number of other personality characteristics in the context of establishing the general level stress of young women and young men who study and are in the stage of preparation for the exams (situational component of educational stress), and indirectly - the stress resistance of their organs in general, moreover, determining the level of emotional burnout and the degree of formation of its individual phases, namely: phases of alarm voltage, resistance and exhaustion $[1,5,10,22]$ play an important role in the implementation of this process.

Our studies have established evidence of an increase in the expression of all the leading phases of emotional burnout of students to be studied during the pre-examination and examination periods ( 1 month before the beginning of the examination session and immediately before the beginning of the exam respectively) and most of all this phenomenon concerns the most unfavorable in its content of phases of resistance and exhaustion. In particular, it was found that among young women, a more significant degree of expression of values that mark the leading components of the resistance phases is recorded, among young men - values that mark the leading indicators of the phases of alarm voltage and exhaustion.

Of particular note is the fact that the level of expression of the leading characteristics of emotional burnout of the largest part of subjects was characterized by being in the phase of resistance and 1 month before the exam session, and immediately before the exam session. However, the highest level of expression of the indicators of the phase of stress among both young women and young men was characteristic for the period of 1 month before the examination session, instead, the highest level of

\section{References}

[1] Aherne, D., Farrant, K., Hickey, L., Hickey, E., McGrath, L., \& McGrath, D. (2016). Mindfulness based stress reduction for medical students: optimising student satisfaction and engagement. BMC medical education, 16(1), 209.

[2] Al Rasheed, F., Naqvi, A. A., Ahmad, R., \& Ahmad, N. (2017). Academic stress and prevalence of stress-related selfmedication among undergraduate female students of health and non-health cluster colleges of a public sector university in Dammam, Saudi Arabia. Journal of pharmacy \& bioallied sciences, 9(4), 251

[3] Backović, D. V., llić Živojinović, J., Maksimović, J., \& Maksimović, M. (2012). Gender differences in academic stress and burnout among medical students in final years of education. Psychiatria Danubina, 24(2), 175-181.

[4] Bedewy, D., \& Gabriel, A. (2013). The Development and expression of indicators of the phase of exhaustion among both young women and young men was characteristic for the period immediately before exam session.

The determined data are of considerable importance both from the standpoint of determining the features of formation of adaptive resources of the organism of young women and young men studying in institutions of higher education of medical profile, and from the standpoint of establishing practically significant approaches to the formation of students' personality, ensuring the formation of the necessary for successful mastering the future specialty of the working dynamic stereotype of performing educational and professional activities and preventing the occurrence of unwanted emotional reactions in response to the action of factors educational or work process.

\section{Conclusions}

1. The results obtained indicate a increase in the degree of expression of all the leading phases of emotional burnout of students during the pre-exam and exam periods (1 month before the beginning of the exam session and immediately before the beginning of the exam session respectively) and most of all this phenomenon concerns the most unfavorable in its content of phases of resistance and exhaustion.

2. It is established that the level of expression of the leading characteristics of emotional burnout in the highest proportion of young women and young men is characterized by being in the phase of resistance. The highest level of expression of emotional burnout phase indicators in both young women and young men is characteristic for the period of 1 month before the exam session, however, the highest level of expression of indicators of the phase of exhaustion both in young women and young men are observed immediately before the exam session.

3. Young women have more significant degree of expression of values that mark the leading components of the resistance phase, among young men - values that mark the leading indicators of the phases of stress and exhaustion.

Psychometric Assessment of a Scale to Measure the Severity of Examination Anxiety among Undergraduate University Students. International journal of educational psychology, 2(1), 81-104.

[5] Bodrov, V. A. (2006). Psychology of professional activity. Theoretical and applied problems. Moscow: Publishing house "Institute of Psychology RAS".

[6] Brennan, N., Corrigan, O., Allard, J., Archer, J., Barnes, R., Bleakley, A., ... \& De Bere, S. R. (2010). The transition from medical student to junior doctor: today's experiences of Tomorrow's Doctors. Medical education, 44(5), 449-458.

[7] Dyrbye, L. N., Thomas, M. R., \& Shanafelt, T. D. (2006). Systematic review of depression, anxiety, and other indicators of psychological distress among US and Canadian medical students. Academic medicine, 81(4), 354-373. 
[8] Gorter, R. C. (2001). Burnout among dentists: a question of coping. Nederlands tijdschrift voor tandheelkunde, 108(11), 458-461.

[9] Hagger, M. S., \& Chatzisarantis, N. L. (2011). Causality orientations moderate the undermining effect of rewards on intrinsic motivation. Journal of Experimental Social Psychology, 47(2), 485-489. doi: 10.1016/j.jesp.2010.10.010

[10] Higuchi D., \& Echigo A. (2016). Characteristics of coping strategies and the relationships between coping strategies and stress reactions in physical therapy students during clinical practice. Journal of physical therapy science, $28(10)$, 2867-2870.

[11] Kim, K. J. (2016). Factors associated with medical student test anxiety in objective structured clinical examinations: a preliminary study. International journal of medical education, $7,424$.

[12] Kötter T., \& Niebuhr F. (2016). Resource-oriented coaching for reduction of examination-related stress in medical students: an exploratory randomized controlled trial. Advances in medical education and practice, 7, 497.

[13] Kuhlmann, S. M., Huss, M., Bürger, A., \& Hammerle, F. (2016). Coping with stress in medical students: results of a randomized controlled trial using a mindfulness-based stress prevention training (MediMind) in Germany. BMC medical education, 16(1), 316

[14] Kumar Pandey, A., \& LPandey, B. (2017). Neurophysiology of Social Conduct and Impact of Adverse Exposures. Avicenna Journal of Neuro Psycho Physiology, 4(1), 1-8. doi: 10.5812/ ajnpp.12452

[15] McAdams, D. P., \& Olson, B. D. (2010). Personality development: Continuity and change over the life course. Annual review of psychology, 61, 517-542. doi: 10.1146/ annurev.psych.093008.100507

[16] Meares, R., Gerull, F., Stevenson, J., \& Korner, A. (2011). Is self disturbance the core of borderline personality disorder? An outcome study of borderline personality factors. Australian \& New Zealand Journal of Psychiatry, 45(3), 214-222. doi: 10.3109/00048674.2010.551280

[17] Myers, H. L., \& Myers, L. B. (2004). 'It's difficult being a dentist': stress and health in the general dental practitioner. British dental journal, 197(2), 89.

[18] Orn, P. (1997) Stress and burnout among physicians. Similar problems in different health care systems. Lakartidningen, 94(22), 2052

[19] Oxley, D. R., Smith, K. B., Alford, J. R., Hibbing, M. V., Miller, J. L., Scalora, M., ... \& Hibbing, J. R. (2008). Political attitudes vary with physiological traits. Science, 321(5896), 1667-1670.
[20] Petrov, M. E., Lichstein, K. L., \& Baldwin, C. M. (2014). Prevalence of sleep disorders by sex and ethnicity among older adolescents and emerging adults: relations to daytime functioning, working memory and mental health. Journal of adolescence, 37(5), 587-597.

[21] Pöhlmann, K., Jonas, I., Ruf, S., \& Harzer, W. (2005). Stress, burnout and health in the clinical period of dental education. European journal of dental education, 9(2), 78-84.

[22] Raygorodskiy, D. Y. (2011). Practical psychodiagnostics. Techniques and tests. Samara: Publishing house "BahrahM".

[23] Schauer, M., \& Elbert, T. (2015). Dissociation following traumatic stress. Zeitschrift für Psychologie/Journal of Psychology.

[24] Serheta, I. V., Bratkova, O. Y., Mostova, O. P., Panchuk, O. Y., \& Dudarenko, O. B. (2012). Scientific principles of psychohygienic diagnostics of the health of children, adolescents and youth. Environment and health, 4(64), 2125.

[25] Serheta, I. V., Grigorchuk, L. I., \& Molchanova, O. P. (2002). Ways of optimization of professional adaptation of students to the conditions of study at a medical higher educational institution and their predictive value. Environment and health, 4(23), 57-61.

[26] Serheta, I. V., Panchuk, O. Y., Stoyan, N. V., Drezhenkova, I. L., \& Makarov, S. Y. (2016). University hygiene in the context of implementation of the "Law on Higher Education": physiological and hygienic bases, realities and ways of development. Environment and health, 4(80), 46-52.

[27] Shim, E. J., Jeon, H. J., Kim, H., Lee, K. M., Jung, D., Noh, H. L., ... \& Hahm, B. J. (2016). Measuring stress in medical education: validation of the Korean version of the higher education stress inventory with medical students. BMC medical education, 16(1), 302.

[28] Weber, K., Miller, G. A., Schupp, H. T., Borgelt, J., Awiszus, B., Popov, T., ... \& Rockstroh, B. (2009). Early life stress and psychiatric disorder modulate cortical responses to affective stimuli. Psychophysiology, 46(6), 1234-1243. doi: 10.1111/ j.1469-8986.2009.00871.x

[29] Weier, M., \& Lee, C. (2016). Stagnant or successful, carefree or anxious? Australian university students' goals and beliefs about adulthood and their current well-being. Australian Psychologist, 51(6), 422-430.

[30] Welch, S. S., Linehan, M. M., Sylvers, P., Chittams, J., \& Rizvi, S. L. (2008). Emotional responses to self-injury imagery among adults with borderline personality disorder. Journal of Consulting and Clinical Psychology, 76(1), 45-51. doi: 10.1037/0022-006X.76.1.45

\section{ОСОБЛИВОСТІ ЕМОЦІЙНОГО ВИГОРАННЯ СТУДЕНТІВ В УМОВАХ ПЕРЕДЕКЗАМЕНАЦІЙНОГО ТА ЕКЗАМЕНАЦІЙНОГО НАВЧАЛЬНОГО СТРЕСУ \\ Серебреннікова О. А., Макаров С. Ю.}

Важливе місце у структурі особливостей особистості студентської молоді, яка оволодіває певним фахом і перебуває в умовах передекзаменаційного та екзаменаційного навчального стресу, належить провідним характеристикам рівня вираження емоційного вигорання, що є незаперечним чинником фрормування високого рівня емоційної нестійкості дівчат $i$ юнаків до дії чинників довкілля та соціальних і професійних умов життя. Метою роботи є дослідження особливостей емоційного вигорання студентів закладів вищої медичної освіти, які перебувають в умовах передекзаменаційного та екзаменаційного навчального стресу. Дослідження проводились на базі Вінницького національного медичного університету ім. М. І. Пирогова серед 67 студентів 3 курсу медичного фракультету відповідно за 1 місяць до складання та безпосередньо перед періодом складання дифреренційованих заліків і проведенням екзаменаційної сесії із використанням особистісного опитувальника Бойка. Статистичний аналіз одержаних даних, що передбачав застосування процедур описової статистики, здійснювався на основі використання стандартного пакету прикладних програм статистичного аналізу "Statistica 6.1" (ліцензійний № AXX910A374605FA). Отримані результати засвідчують суттєве збільшення показників ступеня вираження усіх провідних фраз емоційного вигорання студентів протягом передекзаменаційного та екзаменаційного періодів, причому 
в найбільшій мірі це явище стосується найбільш несприятливих за своїм змістом фраз резистентності та виснаження. Встановлено, що рівень вираження провідних характеристик емоційного вигорання у найбільшої частки дівчат і юнаків характеризується перебуванням у фразі резистентності. Найбільш високий ступінь вираження показників фрази напруження емоційного вигорання і у дівчат, і у юнаків властивий для періоду за 1 місяць до екзаменаційної сесії, разом з тим, найбільш високий рівень вираження показників фрази виснаження і у дівчат, і у юнаків спостерігається безпосередньо перед екзаменаційною сесією. Серед дівчат реєструється більш значущий ступінь вираження величин, які відзначають провідні складові фрази резистентності, серед юнаків - величин, які відзначають провідні показники фраз напруження та виснаження. Одержані результати мають суттєву значущість як з позицій визначення особливостей формування адаптаційних ресурсів організму, так і з позицій встановлення практично-значущих підходів до формування особистості студентів, що забезпечують становлення необхідного для успішного засвоєння майбутнього фраху робочого динамічного стереотипу виконання навчальної і профресійної діяльності та запобігання виникненню небажаних емоційних реакцій у відповідь на дію чинників навчального або трудового процесу.

Ключові слова: студенти, заклади вищої медичної освіти, емоційне вигорання, передекзаменаційний та екзаменаційний навчальний стрес.

\section{ОСОБЕННОСТИ ЭМОЦИОНАЛЬНОГО ВЫГОРАНИЯ СТУДЕНТОВ В УСЛОВИЯХ ПРЕДЭКЗАМЕНАЦИОННОГО И ЭКЗАМЕНАЦИОННОГО УЧЕБНОГО СТРЕССА \\ Серебренникова О. А., Макаров С. Ю.}

Важное место в структуре личностных особенностей студенческой молодежи, овладевающей определенной специальностью и находящейся в условиях предэкзаменационного и экзаменационного учебного стресса, принадлежит ведущим характеристикам степени выраженности эмоционального выгорания, являющегося неотъемлемым фрактором формирования высокого уровня эмоциональной неустойчивости девушек и юношей к воздействию фракторов окружающей среды, социальных и профессиональных условий жизни. Целью работы является исследование особенностей эмоционального выгорания студентов учреждений высшего медицинского образования, находящихся в условиях предэкзаменационного и экзаменационного учебного стресса. Исследования проводились на базе Винницкого национального медицинского университета им. Н. И. Пирогова среди 67 студентов 3 курса медицинского факультета соответственно за 1 месяц до сдачи и непосредственно перед сдачей дифреренцированных зачетов и проведением экзаменационной сессии $c$ использованием личностного опросника Бойко. Статистический анализ полученных данных, предусматривающий применение процедур описательной статистики, осуществлялся на основе использования стандартного пакета прикладных программ статистического анализа "Statistica 6.1" (лицензионный № AXX910A374605FA). Полученные результаты свидетельствуют о существенном увеличении показателей степени выраженности ведущих фраз эмоционального выгорания студентов на протяжении предэкзаменационного и экзаменационного периодов, причем в наибольшей степени данное явление касалось наиболее неблагоприятных по своему содержанию фраз резистентности и истощения. Установлено, что уровень выраженности ведущих характеристик эмоционального выгорания у наибольшей части девушек и юношей характеризуется пребыванием в фразе резистентности. Наиболее высокая степень выраженности показателей фразы напряжения эмоционального выгорания и у девушек, и у юношей свойственна для периода за 1 месяц до экзаменационной сессии, вместе с тем, наиболее высокий уровень выраженности показателей фразы истощения и у девушек, и у юношей наблюдается непосредственно перед экзаменационной сессией. У девушек регистрируется более значимая степень выраженности величин, характеризующих ведущие составляющие фразы резистентности, среди юношей - величин, характеризующих ведущие составляющие фраз напряжения и истощения. Полученные данные имеют существенную значимость как с позиций определения особенностей фрормирования адаптационных ресурсов организма, так и с позиций установления практически значимых подходов к формированию личности студентов, обеспечивающих становление необходимого для успешного овладения будущей профрессии рабочего динамического стереотипа, адекватного выполнения учебной и профессиональной деятельности, а также предупреждения возникновения неблагоприятных эмоциональных реакций в ходе воздействия факторов учебного либо трудового процесса.

Ключевые слова: студенты, учреждения высшего медицинского образования, эмоциональное выгорание, предэкзаменационный и экзаменационный учебный стресс. 